\title{
Indium-111 leucocyte scintigraphy in the investigation and management of inflammatory bowel disease
}

\author{
K.J. Fotherby ${ }^{1}$, E.P. Wraight ${ }^{2}$, H. Garforth ${ }^{2}$ and J.O. Hunter ${ }^{1}$ \\ Departments of ' Gastroenterology and ${ }^{2}$ Nuclear Medicine, Addenbrooke's Hospital, Cambridge CB2 2QQ, UK.
}

\begin{abstract}
Summary: The results of indium-111 tropolonate leucocyte scintigraphy in 105 patients with known inflammatory bowel disease are reviewed. Scintigraphy is as sensitive as radiology in detecting and assessing the extent of active colonic disease, and probably more sensitive in assessing small bowel disease. In a further 40 patients scintigraphy was successfully used as a screening test to identify, or exclude, bowel inflammation in patients with gastrointestinal symptoms. Scintigraphy has advantages over barium studies, being safe, non-invasive, more sensitive than small bowel radiology and giving additional information such as the bowel identification of intra-abdominal abscesses. The time required to label the leucocytes (about 2 hours) and the higher unit cost, unless many scintigrams are performed, are disadvantages.
\end{abstract}

\section{Introduction}

Although several small studies of indium-111 leucocyte scintigraphy have suggested that it may be of value in the management of chronic inflammatory bowel disease (CIBD), large scale studies of its use in clinical practice are lacking. Previous studies have shown that scintigraphy can correlate well with radiology in indicating the site and extent of inflammation affecting the colon (Saverymuttu et al., 1982; Stein et al., 1983a). In ileal disease, although scintigraphy may indicate the presence of inflammation, it is not always accurate in defining its extent (Saverymuttu et al., 1983a). In addition, scintigraphy is non-invasive and may identify abscesses (Saverymuttu et al., 1983b; Ambrose et al., 1983) and indicate the severity of disease affecting the colon either directly from the scintigram (Saverymuttu et al., 1984) or from measurement of faecal indium-111 excretion (Saverymuttu et al., 1983c).

Negative scintigrams occur in the irritable bowel syndrome (Saverymuttu et al., 1983a and 1983c) and a recent study (Saverymuttu et al., 1985) shows that scintigraphy identifies those patients presenting with chronic diarrhoea who have CIBD.

Initial experience, however, with indium-111 leucocyte scintigraphy at this hospital was not promising (Buxton-Thomas et al., 1984). Recently, with the introduction of tropolonate as the ionophore, leucocytes can be labelled in plasma with greater

Correspondence: K.J. Fotherby, M.A., M.R.C.P.

Accepted: 3 February 1986 efficiency and less damage (Saverymuttu et al., 1983d). This allows imaging to be carried out at a shorter interval after reinjection and, also, potentially gives more reliable and accurate results. This retrospective study presents our experience with indium-111 tropolonate scintigraphy during the 15 months after its introduction, both in assessing the presence and the extent of inflammation in the bowel.

\section{Methods}

\section{Patients}

The medical records of 145 out of 160 sequential patients were available for review. All were adults and had indium-111 tropolonate scintigraphy between January 1984 and April 1985 to assess known CIBD (105 patients) or to investigate possible CIBD (40 patients). The 105 patients with CIBD consisted of 92 with Crohn's disease (ileo-colonic, colonic and ileal), 11 with ulcerative colitis and 2 unclassified. They were treated with diet, steroids and/or sulphasalazine as clinically indicated. Disease severity was assessed from the records made at the time of scanning according to the criteria of Truelove \& Witts (1955).

\section{Scintigraphy}

Fifty $\mathrm{ml}$ of blood anticoagulated with ACD was sedimented with the aid of plasmasteril for 45 minutes

C The Fellowship of Postgraduate Medicine, 1986 
at $37^{\circ} \mathrm{C}$. The leucocyte-rich-platelet-rich supernatant was removed and centrifuged for 7 minutes at $90 \mathrm{~g}$ to give a pellet of mixed leucocytes. The supernatant was removed and centrifuged at $1300 \mathrm{~g}$ to produce plateletpoor plasma. The mixed leucocytes were washed then labelled using $100 \mu \mathrm{l}$ of tropolone $\left(4.4 \times 10^{-3} \mathrm{M}\right.$ in $20 \mathrm{mM}$ Hepes-saline buffer) followed immediately by the required volume of ${ }^{111} \mathrm{InCl}$. This was incubated at $37^{\circ} \mathrm{C}$ for 5 minutes. The volume of ${ }^{111} \mathrm{InCl}$ was calculated to give a dose of 12 or $16 \mathrm{MBq}$ allowing for a labelling efficiency of at least $75 \%$. About $5 \mathrm{ml}$ of platelet-poor plasma was added to remove any unbound ${ }^{111}$ In. This was mixed, centrifuged then removed but kept. The cells were re-suspended in fresh platelet-poor plasma. The activity in the cells and supernatant was measured to determine the labelling efficiency, and the final volume adjusted to give the required dose.

Initially only anterior, but later also posterior, abdominal images were obtained at 3-4 hours and, if indicated, 18-24 hours after reinjection. A large field of view gamma camera with a medium energy collimator was used. In order to assess the clinical usefulness of these studies the scintigram reports made by a nuclear medicine physician (usually EPW) and not the scintigrams themselves were reviewed to assess disease location and extent.

\section{Other investigations}

Sixty five patients had 82 radiological studies (doublecontrast barium enemas, barium follow-throughs and small bowel enemas), 38 within 2 weeks, 33 within 2 to 6 weeks and 11 within 6 to 12 weeks of scintigraphy. In addition 6 patients had colonoscopies and 11 laparotomies within 3 months of scintigraphy.

\section{Results}

One-hundred and fifty-six scintigrams were performed ( 1 patient, 4,1 patient 3 and 6 patients 2 each); 10 scintigrams in 9 patients with CIBD showing coexisting abscesses are analysed separately, leaving 91 positive and 55 negative studies (Table I).

\section{Positive scintigrams}

Forty-five patients (41 known IBD, 4 other) had 36 barium enema and 20 small bowel study reports available to compare the extent of disease shown. There was major and clinically important disagreement in only 6 cases (Table II) and another 23 patients showed excellent agreement. Scintigrams, where discrepancies existed, were reviewed blind by EPW without any change being made from the original interpretation. In the remaining 16 , minor disagreement and/or uncertainty over the exact localization or extent of radionuclide uptake was present. In the 16 patients, the extent of uptake appeared greater than the extent of disease shown on barium studies in 6 scintigrams and less in 2 . In 8 scintigrams it was not possible to determine whether right iliac fossa radionuclide uptake represented inflammation in the terminal ileum or in the caecum, or, if an ascending colitis was present to exclude coexistent terminal ileal disease. In 5 scintigrams it was uncertain whether the distal extent of radionuclide uptake represented colonic inflammation or merely luminal leucocytes shed from a more proximal site.

Fifteen of the above 45 scintigrams showing ileal disease (with or without colonic disease) and where a barium follow-through had been performed within a fortnight were also assessed separately for comparison of the extent of ileal inflammation shown. Five of the 8 scintigrams showing disease confined to the terminal ileum agreed with barium studies, but in 3 , barium studies were normal (patients 2 and 3, Table II, and a third with known distal Crohn's disease). The other 7 scintigrams showed that small bowel disease was either not confined to the terminal ileum or only affected more proximal bowel. Of these, barium studies agreed in 4, showed only terminal ileal disease in 2 and were normal in 1 patient where radionuclide uptake had been incorrectly localized to the small bowel (patient 7, Table II).

Forty-five positive scintigrams for which no barium studies were available for comparison were performed in 38 patients with clinically active and known CIBD and in 1 patient with pseudomembranous colitis.

Some patients (Table III) with positive scintigraphy had normal erythrocyte sedimentation rates (ESR $<20 \mathrm{~mm} / \mathrm{h}$ ) and no elevation of acute phase reactants $\left(\alpha_{1}\right.$-antitrypsin, orosomucoid and haptaglobin). This was more likely to occur when the scintigram showed ileal disease.

Table I Scintigram results in patients with and without established CIBD

\begin{tabular}{lcc}
\hline & $\begin{array}{c}\text { Established CIBD } \\
96 \text { patients }\end{array}$ & $\begin{array}{c}\text { Other } \\
40 \text { patients }\end{array}$ \\
\hline $\begin{array}{l}\text { Positive } \\
\text { scintigrams }\end{array}$ & 86 (in 79 patients) & 5 \\
$\begin{array}{l}\text { Negative } \\
\text { scintigrams }\end{array}$ & 20 (in 17 patients) & 35 \\
$\begin{array}{l}\text { Total number of } \\
\text { scintigrams }\end{array}$ & 106 & 40 \\
\hline
\end{tabular}


Table II Patients showing major disagreement between scintigrams and barium studies. $(\mathrm{BaE} \times \mathrm{barium}$ enema; BaFT $=$ barium follow-through; $\mathrm{SBE}=$ small bowel enema; +1 week = barium study one week after scintigram etc.).

\begin{tabular}{|c|c|c|c|c|}
\hline \multicolumn{2}{|c|}{ Patient } & \multirow{2}{*}{$\begin{array}{l}\text { Scintigram result } \\
\text { Pancolitis }\end{array}$} & \multirow{2}{*}{$\begin{array}{l}\text { Other investigation } \\
\text { BaE }+3 \text { days: normal } \\
\text { colonoscopy }+5 \text { days: } \\
\text { pancolitis }\end{array}$} & \multirow{2}{*}{$\begin{array}{r}\text { Scintigram } \\
\text { True + ve }\end{array}$} \\
\hline 1 & $\begin{array}{l}29 \text { year old female } \\
\text { ulcerative colitis } 6 \text { years }\end{array}$ & & & \\
\hline 2 & $\begin{array}{l}23 \text { year old female } \\
\text { Crohn's proctitis }\end{array}$ & Terminal ileitis & BaFT +2 weeks: normal & ? False + ve \\
\hline 3 & $\begin{array}{l}25 \text { year old female } \\
\text { Crohn's proctitis }\end{array}$ & Terminal ileitis & SBE +2 days: normal & ? False + ve \\
\hline 4 & $\begin{array}{l}75 \text { year old female diarrhoea } \\
10 \text { years. ? diagnosis }\end{array}$ & $\begin{array}{l}\text { Loop of small bowel and } \\
\text { transverse colon inflamed }\end{array}$ & $\begin{array}{l}\text { BaFT }-2 \text { weeks: normal } \\
\text { BaE }-1 \text { week: normal } \\
\text { colonoscopy }+4 \text { week: } \\
\text { normal }\end{array}$ & ? False + ve \\
\hline 5 & $\begin{array}{l}35 \text { year old female } \\
\text { abdominal pain, diarr- } \\
\text { hoea } 5 \text { years. ? diagnosis }\end{array}$ & Pancolitis & $\begin{array}{l}\text { SBE - } 10 \text { weeks: normal } \\
\text { colonoscopy }+4 \text { weeks: } \\
\text { normal }\end{array}$ & ? False + ve \\
\hline 6 & $\begin{array}{l}32 \text { year old male } \\
\text { Crohn's } 1 \text { year }\end{array}$ & Normal & $\begin{array}{l}\text { BaFT }-1 \text { week: terminal } \\
\text { ileitis. Colonoscopy }+4 \\
\text { weeks: normal }\end{array}$ & False - ve \\
\hline 7 & $\begin{array}{l}30 \text { year old female } \\
\text { colitis } 2 \text { years. ? type }\end{array}$ & $\begin{array}{l}\text { Loop of small bowel \& } \\
\text { transverse colon inflam- } \\
\text { ed suggesting Crohn's }\end{array}$ & $\begin{array}{l}\mathrm{BaE}+2 \text { weeks: pancolitis } \\
\mathrm{BaFT}+3 \text { days: normal }\end{array}$ & $\begin{array}{l}\text { True }+ \text { ve but diagnosis } \\
\text { of ulcerative colitis } \\
\text { established }\end{array}$ \\
\hline
\end{tabular}

\section{Negative scintigrams}

Fifty-two patients had negative scintigrams but only 22 of these patients (9 CIBD, 13 other) had barium studies performed. One barium study was abnormal identifying a false negative scintigram (patient 6 , Table II).

The 17 patients in this group known to have a history of CIBD all had mild symptoms. The other 35 patients had scintigrams performed to exclude CIBD. Twenty-eight of these latter patients have been foll- owed up and their symptoms either resolved spontaneously, resolved after an exclusion diet confirming IBS (Hunter et al., 1985), or an alternative non-inflammatory diagnosis was accepted (diabetic diarrhoea, post-vagotomy diarrhoea, lymphoma).

\section{Abscesses in CIBD}

Scintigrams were performed in 4 patients with known abscesses, 7 with possible abscesses (right iliac fossa mass palpable or post-operative fever) and in 4 the

Table III Comparison of scintigram results with ESR (mm/first hour) and acute phase reactant levels (AP; $\alpha_{1}$-antitrypsin, orosomucoid and haptaglobin) measured in the fortnight preceeding the scintigram

\begin{tabular}{lcccc}
\hline & $\begin{array}{c}\text { ESR }<20 \\
\text { and } \\
\text { normal AP }\end{array}$ & $\begin{array}{c}\text { ESR }<20 \\
\text { but } \\
\text { elevated AP }\end{array}$ & $\begin{array}{c}\text { ESR }>20 \\
\text { and } \\
\text { elevated AP }\end{array}$ & $\begin{array}{c}\text { ESR 20-30 } \\
\text { but }\end{array}$ \\
\hline $\begin{array}{l}\text { CIBD } \\
\text { Positive scintigram }(n=62)\end{array}$ & 13 & 11 & 35 \\
$\begin{array}{l}\text { CIBD } \\
\text { Negative scintigram }(n=16)\end{array}$ & 11 & $2 *$ & 3 \\
$\begin{array}{l}\text { CIBD excluded } \\
\text { Negative scintigram }(n=24)\end{array}$ & 24 & 0 & 0 & 2 \\
\hline
\end{tabular}

\footnotetext{
${ }^{*}=$ Acute phase elevated less than $25 \%$ above normal range; ${ }^{* *}=$ False negative scan (patient 6 , Table II).
} 
scintigram suggested an unsuspected abscess. These 15 patients underwent surgery (4), ultrasonography (7) and computed tomographic (CT) scanning (6). The final diagnosis in the 12 patients with scintigrams suggesting an abscess, either alone or with active CIBD, was an abscess in 8 (including 1 wound abscess), an inflammatory mass in 2 , infection in a known fistula in 1 and 1 false positive scintigram. In 3 patients scintigraphy, although showing active CIBD, did not identify an abscess. One of these scintigrams negative for abscess may have been incorrect as an abscess, suspected clinically, was found at surgery 4 months later. However, ultrasonography at the time of scintigraphy was also negative.

\section{Discussion}

This retrospective study of a large series of indium-111 tropolonate scintigrams confirms that they can accurately assess the extent of disease in known CIBD and are also useful screening tests to identify, or exclude bowel inflammation. However, a positive scintigram is not specific for CIBD, occurring in any disease associated with bowel inflammation whether idiopathic, infective, radiation-induced or secondary to ischaemic colitis or enteritis (Saverymuttu et al., 1983e; Stein et al., 1983b) and also in gastrointestinal haemorrhage (Stein et al., 1983b) where white cells are also shed into the bowel lumen.

In the assessment of disease location and the extent of active CIBD there was excellent agreement with barium studies with significant discrepancy in only 4 of the 49 patients. One of these patients had a true positive scintigram (patient 1 , Table II) confirmed by colonoscopy and another a false negative (patient 6) confirmed by surgery. Two patients had possible false positive scintigrams but as both (patients 2 and 3) had a confirmed Crohn's proctitis a terminal ileitis as suggested by scintigraphy cannot be totally excluded by the normal barium studies. Neither patient was taking non-steroidal anti-inflammatory drugs which can cause terminal ileal radionuclide uptake (Bjarnason et al., 1984).

Seventeen patients with CIBD, but mild symptoms, had negative scintigrams. The possibility that some of these were false negatives occurring in the presence of mild inflammation cannot be excluded. However, 9 patients also had normal barium studies and, therefore, scintigraphy is no less sensitive than radiology. Saverymuttu et al. (1985) found that 2 of 33 patients with CIBD had negative scintigrams. Both patients had mild symptoms with a Crohn's disease activity index less than 100 , normal radiological studies but abnormal rectal histology.

This study is the first to show that indium-111 tropolonate scintigrams can distinguish between ileal disease confined to the terminal ileum and disease that is either more extensive or localized to other loops of small bowel. In 3 patients it showed terminal ileal disease not found on barium follow-through and in another 2 patients showed more extensive small bowel disease than radiology. Both investigations were performed within a fortnight and this suggests that scintigraphy is more sensitive than radiology in detecting small bowel Crohn's disease. However, if radionuclide uptake in the right iliac fossa is very localized it may be impossible to identify it as terminal ileal or caecal as anatomical localization requires the recognition of characteristic patterns of radionuclide uptake (Figures 1 and 2). In clinical practice, however, it is more important to be aware that inflammation is present than to know its precise site in the right iliac fossa.

Scintigraphy appears to be slightly more sensitive than the ESR or acute phase reactants for indicating the presence of inflammation (Table III). This superiority and the possibility that, for ileal disease at least, scintigraphy may be more sensitive than radiology suggests than it may be useful to distinguish between recurrent ileal disease and bile salt malabsor-

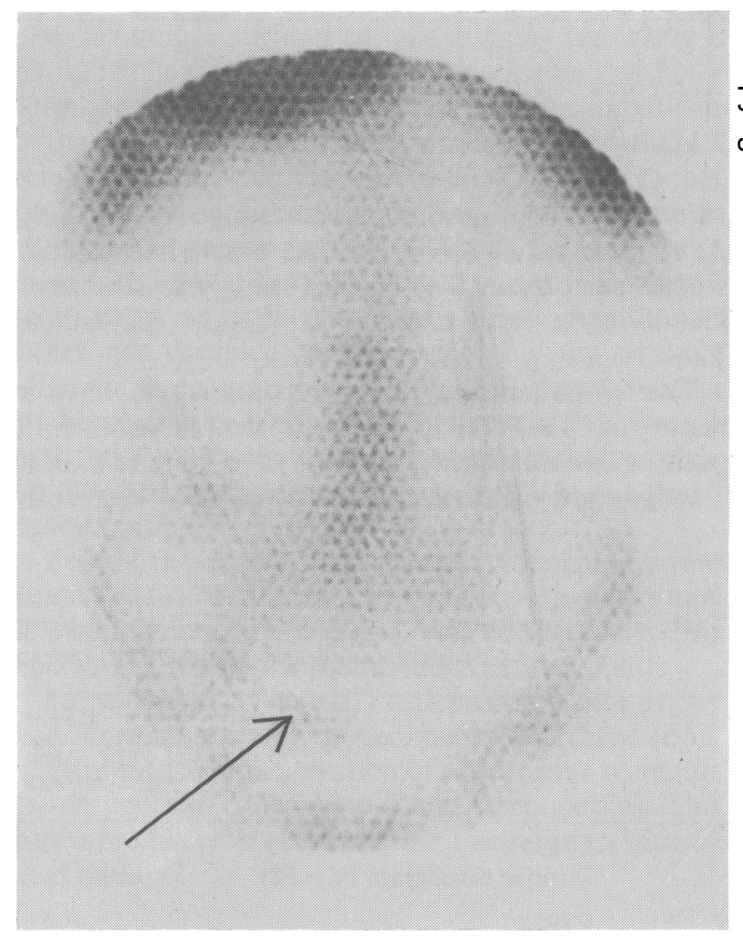

Figure 1 Indium-111 leucocyte scintigram (4 hour) showing radionuclide uptake in the terminal ileum (arrowed) and normal uptake in the spleen, liver and bonemarrow. Terminal ileal Crohn's disease subsequently confirmed by barium follow-through. 


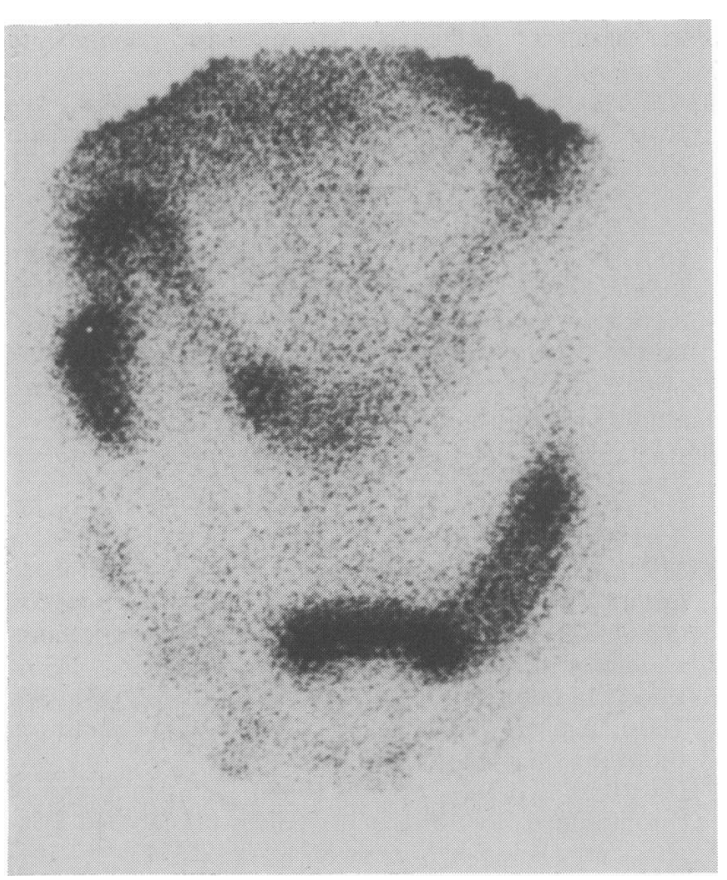

Figure 2 Indium-111 leucocyte scintigram (4 hour) in a patient with pancolitis. Crohn's pancolitis confirmed at pan-proctocolectomy.

ption as a cause for symptoms following ileal resection. Also, as scintigraphy does not detect the chronic changes of Crohn's disease, it should distinguish fibrotic strictures requiring surgery from inflammatory strictures which may respond to medical or dietary therapy (Alun Jones et al., 1985). We have used scintigraphy for these indications, but as yet do not have enough data to confirm its value.

As a screening test in the 40 patients without known CIBD there appeared to be no false negatives on follow-up. Two patients initially suspected of having IBS had positive studies and subsequently confirmatory radiology. Patients 4 and 5 (Table II) may have had false positive scans, as post-mortem and colonoscopic examinations, respectively, were normal. However, in neither case was a definite diagnosis

\section{References}

ALUN JONES, V., DICKINSON, R.J., WORKMAN, E., WILSON, A.J., FREEMAN, A.H. \& HUNTER, J.O. (1985). Crohn's disease: maintenance of remission by diet. Lancet, ii, 177.

AMBROSE, N.S., GOLDMAN, M., HAWKER, R.J., DROK, Z., established, and inflammation other than CIBD may have caused the positive scintigrams.

Scintigrams have some advantages over barium studies. They are non-invasive, do not require bowel preparation and are safe in severe CIBD. Abscesses may be identified (Saverymuttu et al., 1983b; Ambrose et al., 1983) although as persistent localized isotope uptake can occur in CIBD (usually radionuclide moves distally in the faecal stream in CIBD but remains static within an abscess on sequential imaging) false positives can occur. One possible false negative for abscess also occurred. Disease severity is most accurately assessed by measuring faecal excretion of labelled leucocytes (Saverymuttu et al., 1983c). However, the 4 day stool collections required are impracticable when large numbers of patients, including out-patients are being studied. Assessing severity directly by visual grading of the intensity of radionuclide uptake on the scintigram correlates well with faecal indium excretion in colonic disease (Saverymuttu et al., 1984). The excellent visualization of small bowel disease on many scintigrams in this study suggests that the severity of small bowel disease may also be reliably so assessed. However, this retrospective study was not suitable for assessing the accuracy of scintigrams in gauging disease severity.

The major disadvantage, at present, of scintigraphy is the time required to label the leucocytes ( 2 hours). Whole body radiation exposure is approximately $2 \mathrm{mSv}$ but maximum radiation exposure to the target organ, the spleen, is $60 \mathrm{mSv}$ following the $12 \mathrm{MBq}$ dose used for detecting inflammatory bowel disease (Thakur et al., 1977). This radiation exposure to the spleen is similar to that from a barium enema together with a barium follow-through, and limits the number of times scintigraphy can be performed. Indium binds within the cytoplasm and nucleus, causing chromosomal damage. This is unimportant in the short-lived leucocyte but, potentially, could cause lymphoid malignancy. However, any lymphocytes incidentally labelled in the leucocyte preparation are thought to be destroyed by the radiation and pose no long term risk (Thakur \& McAfee, 1984).

Indium-111 tropolonate scintigraphy is a reliable alternative to barium studies in the assessment of known CIBD in relapse and can be used as a screening test to identify, or exclude, diseases causing bowel inflammation as a cause of gastrointestinal symptoms.

KEIGHLEY, M.R.B. \& McCOLLUM, C.N. (1983). Differentiation between abscess formation and active Crohn's disease using indium-111 labelled leucocyte gamma imaging. Gut, 24, A463.

BJARNASON, I., WILLIAMS, P., SO, A., ZANELLI, G.D., LEVI, 
A.J., GUMPEL, J.M., PETERS, T.J. \& ANSELL, B. (1984). Intestinal permeability and inflammation in rheumatoid arthritis: effects of non-steroidal anti-inflammatory drugs. Lancet, ii, 1171.

BUXTON-THOMAS, M.S., DICKINSON, R.J., MALTBY, P., HUNTER, J.O. \& WRAIGHT, E.P. (1984). Evaluation of indium scintigraphy in patients with active inflammatory bowel disease. Gut, 25, 137.

HUNTER, J.O., WORKMAN, E. \& ALUN JONES, V. (1985). The role of diet in the management of irritable bowel syndrome. In Topics of Gastroenterology, vol. 12. Gibson, P.R. \& Jewell, D.P. (eds). p. 305. Blackwell Scientific Publications: Oxford.

SAVERYMUTTU, S.H., PETERS, A.M., HODGSON, H.J., CHADWICK, V.S. \& LAVENDER, J.P. (1982). Indium-111 autologous leucocyte scanning: comparison with radiology for imaging the colon in inflammatory bowel disease. British Medical Journal, 285, 255.

SAVERYMUTTU, S.H., PETERS, A.M., HODGSON, H.J., CHADWICK, V.S. \& LAVENDER, J.P. (1983a). Indium-111 leucocyte scanning in small bowel Crohn's disease. Gastrointestinal Radiology, 8, 157.

SAVERYMUTTU, S.H., CROFTON, M.E., PETERS, A.M. \& LAVENDER, J.P. (1983b). Indium-111 tropolonate leucocyte scanning in the detection of intra-abdominal abscesses. Clinical Radiology, 35, 593.

SAVERYMUTTU, S.H., PETERS, A.M., LAVENDER, J.P., PEPYS, M.B., HODGSON, H.J. \& CROFTON, M.E. (1983c). Quantitative fecal indium-111 labelled leucocyte excretion: the assessment of disease in Crohn's disease. Gastroenterology, 85, 1333.

SAVERYMUTTU, S.H., PETERS, A.M., DANPURE, H.J., REAVY, H.J., OSMAN, S. \& CROFTON, M.E. (1983d). Lung transit of indium-111 labelled granulocytes. Relationship to labelling techniques. Scandinavian Journal of Haematology, 30, 151.

SAVERYMUTTU, S.H., PETERS, A.M., LAVENDER, J.P., HODGSON, H.J. \& CHADWICK, V.S. (1983e). 111-Indium autologous leucocytes in inflammatory bowel disease. Gut, 24, 293.

SAVERYMUTTU, S.H., CAMILLERI, M., REES, H., LAVENDER, J.P., CHADWICK, V.S. \& HODGSON, H.J. (1984). Indium-111 granulocyte scanning in the assessment of disease extent and severity in colonic inflammatory bowel disease - a comparison with colonoscopy, histology and faecal indium-111 granulocyte excretion. Gastroenterology, 86, 1233.

SAVERYMUTTU, S.H., PETERS, A.M., CROFTON, M.E., REES, H., LAVENDER, J.P., HODGSON, H.J. \& CHADWICK, V.S. (1985). Indium-111 autologous granulocytes in the detection of inflammatory bowel disease. Gut, 26, 955.

STEIN, D.T., GRAY, G.M., GREGORY, P.B., ANDERSON, M., GOODWIN, D.A. \& MCDOUGALL, I.R. (1983a). Location and activity of ulcerative and Crohn's colitis by indium111 leucocyte scan. Gastroenterology, 84, 388.

STEIN, D.T., GOODWIN, D.A. \& MCDOUGALL, I.R. (1983b). The indium-111 WBC scan as a detector of bowel disease. Gastroenterology, 84, 1321.

THAKUR, M.L. \& MCAFEE, J.G. (1984). The significance of chromosomal aberrations in indium-111-labelled lymphocytes. Journal of Nuclear Medicine, 25, 922.

THAKUR, M.L., LAVENDER, J.P., ARNOT, R.N., SILVESTER, D.J. \& SEGAL, A.W. (1977). Indium-111-labelled autologous leucocytes in man. Journal of Nuclear Medicine, 18, 1014.

TRUELOVE, S.C. \& WITTS, L.J. (1955). Cortisone in ulcerative colitis. British Medical Journal, 2, 1041. 